Ciência eNatura, v. 37 Part 2. 2015, p. 08-13

\title{
Effectiveness techniques of resources and expenditures marketing
}

\author{
Sediegheh Taghieh ${ }^{1 *}$, Seyed Keivan Khatami ${ }^{2}$ \\ ${ }^{1}$ Department of accounting, Eghlid Branch,Islamic Azad University Fars Eghlid \\ 2Department of accounting, Damavand Branch,Islamic Azad University Damavand \\ *corresponding author Email: taghieh@yahoo.com
}

\begin{abstract}
Marketing is one of the strategies which can increase bank revenues. Principles and techniques of marketing in view of their applied approaches with regard to bank's financial resources and expenditures and the kind of relationship with clients and practical solutions in order to change and improve clich'e behaviors can be as one of the effective tools in the improvement of behavioral patterns of today's competitive environment. Progress of relationship marketing in bank can be done in line of developing relationship with clients. keeping relationship with clients is a long-term phenomenon and instead of ongoing results future impacts should be the center of attention. In this study concurrent with surveying relationship marketing some cases of their techniques can be studied in general. The method of study, is library method. the result indicates that important factors in the success of banks is to provide rapid services and satisfaction of clients. Therefore dynamic and innovative organization should comply with environment and increasing demands of clients. Then with careful and effective marketing we can realize our purpose of gaining benefit.
\end{abstract}

Keywords: effective techniques, financial resources, bank expenditures, marketing. 


\section{INTRODUCTION}

Today the bank status and its importance and role in the economy of country is evident. The distinguished features of bank in every society have resulted in the development of banks in every social and economic sectors. Efficiency of bank observed in each part of human living. The major task of bank system is to facilitate monetary exchanges required by economy and implementing monetary policies of country. Undoubtedly, the effectiveness of this system can play an influential role in the economic success of country.

In the competitive market of financial services, losing even one client leads to heavy costs for banks and financial institutes. Huge investments in organizations in order to diversify their services and improving quality and desired services is utmost importance.

The purpose of all these in vestments is the satisfaction of present clients and preventing the loss of new clients. Previous researches indicated that with regard to the king of relationship which exists between customers and financial institutions, the relationship marketing becomes important.

In manufacturing marketing strategy,combined services consisted of 8 critical factors which can be called $8 \mathrm{p}$ of service marketing, Similar coherence and compliance exists between every $8 p$, for the success of service occupations.

One of the influential factors in mixed service marketing.

[Farsad,1390]. In the future without frontier competitive market,marketing is a necessity for all countries and organizations. In fact individuals, organizations, and various societies in order to continue their life need to know the market,make the market,and manage the market. But each of these issues cannot be effective without principled and scientific management. In fact marketing management is one of the competitive advantages of companies, because proper management of costs, distribution,sale, promotion, advertisement, lead to a situation in which threats can be transformed to opportunities, and weaknesses in to strengths, and survive in the future difficult and increasing competition [Foruzande,1385] marketing and advertising.

Marketing is a part of trade activity which of recognizing demands for goods and services and providing facilities and distribution channels for their sale and distribution [Arefnejad,1390].

\section{Marketing and advertising}

- Marketing is a part of trade activity which of recognizing demands for goods and services and providing facilities and distribution channels for their sale and distribution [Arefnejad,1390].

- Advertising Is one of the most common tools which used by companies for persuading communication aimed at intended society and audience: advertising consists of disinterested presentation of idea, goods or service by an advertiser requiring paying fees [Forouzandeh,1385].

Marketing managers when preparing and advertising program should always start the job by recognizing and defining intended market and customer's motivation.

Then/ for the development of advertizing program five major decisions should be made. These decisions are as follows: 
mission, money, message,media and measurement [Forouzandeh,1385].

\section{The role of bank strategic techniques in marketing}

This role is of utmost important which we will deal with it ia detail. Marketing manager has a major part in the process of strategic planning. S,he plays a vital role in determining professional mission, analysis of environmental situations, competitive and economic purposes, policies, projects related to goods, markets and distribution policies.

Marketing manager contribution includes developing programs and operational projects related to strategic planning.

In order to understand the meaning of strategic marketing program and developing of strategic marketing strategy suitable for banks, the need to study and survey strategic planning process at organizational, department and unil level is of responsible for developing a large strategic plan ushering in lucrative future. Also this level decides about the dedication of resources to every branch of banks. Every branches managers should plan their own program in which how to dedicate funds and resources to economic units (affiliated branches) can be explained. Every economic unit also embark upon developing marketing plan. Marketing plan acts at two levels.

Strategic marketing plan on the basis of current status of market, deals with sublime aims and policies, marketing and special tactics of marketing buy out packages, pricing, distribution channels and soon... [Venus and colleagues,1384].

\section{Discuss the role of technology in marketing techniques}

Negotiation has different definitions, but the most popular of these definitions as Marian Webster pointed out, negotiation is a process of dialogue for reaching agreement. In American Heritage Dictionary negotiation defined as reaching agreement about sth.

\section{1- Suggested steps for an effective negotiation}

1- Separate individuals from problem when a group of individuals deal with a problem, misunderstanding, stress and anxiety are unavoidable

If we know that the other party is a human being with feeling, values, mental biases and different attitudes and sometimes unpredictable, negotiation becomes more easy. It should be remembered that the other party at negotiation table may be consists of one or more individuals. Before the beginning of negotiation, it is necessary that both parties be prepared psychologically to hold talks and by knowing the other party and predicting potential problems communication, this predication becomes possible[sahraie,1392]

Perception: This skill in which the negotiator put himself in vantage point of another party and see the situation from his point of view is of high importance. Purposeful discussions can define the other party's perception about the topic and as such presenting compatible suggestions can be possible by understanding the other party. Seeing the strengths and weaknesses of the other party, prevents reaching an agreement. [sahraie, 1392]

Emotion: emotions are more important than what we think. By understanding other party's feeling and emotions, they can relieve from the pressures. 
Logical dialogue's become possible. Skillful negotiator can listen and persuade his audience to express their feelings. He cannot react to excitements because there is an obstacle in the way of negotiations.

Communication: without communication, negotiation is impossible. One of the important tools in communication individual's perceptions, know their feeling. You should talk purposefully, use woods with positive connotations.

\section{Focusing on interests of rival}

Recognizing the interests of both parties are among the principles of an effective negotiation. If you like the other party understand your reasons and argumentations/ listen carefully to their interests and reasons. In order to solve the problem logically, you should pay attention to their interests.

Every party has their own different interests. Man's essential heeds are his most important interests. Security, economic welfare, control are among these essential needs. Make a list of different and classified interests of both parties. Never underestimate their interests. Be stable, but flexible. Tackle the problem strenuously, but deal with people moderately. Put your energy on problem and pay attention to future. Never cling to past. Common interests are important opportunities in negotiation process and emphasis on common points result in flexibility of both parties [sahraie,1392]

\section{Creating options for mutual satisfaction}

one of the important points in a successful negotiation is the existence of different options. There are obstacles in the way of accepting the options. These obstacles consist of premature judgement, finding a unique solution, dedicating a given portion to both parties.

In order to remove the obstacles, we should pay attention to creating various option and distinguishing between solutions. Writing options on a board, before seeking a unique solution is of high importance.

In order to reach a mutual agreement one way is to create many options over which there is a concensus, and asking the other party's preferences.

\section{Using objective measures}

Negotiation is on the basis of objective measures. The first and foremost step in creating decision making is to discuss standards and fair processes. It should be noted that we should make decision about the agreed objective measures are agreed upon from the view point of objectivity [sahraie,1392].

\section{Growing of direct marketing and electronic purchasing through traditional direct marketing is rapidly growing.}

Rapid growing is a response to real marketing in go's. Segmentation of market leads to many voids in market. Increasing of traffic jam, concern about finding parking lot, shortage of time, long queus behind bank counters all encourage us to stay at home. Consumers welcomed direct marketing and they are committed to presenting good service to customers. [Forouzandeh,1385].

According to katler(1884) banks are slow in capturing marketing concepts, because traditional bakers need that kind of financial services required by customers marketing of bank services are the product of manufacturing activities and presenting bank series. Marketing flow is very delicate which begins from the beginning of process till the time product reaches to the hand of 
customers, and even after that. Therefore any activity which affects banks and its customers is a part of marketing and should be analyzed from the viewpoint of marketing [Arefnejad and colleagues,1390].Voima mooted a framework for conceptualizing internal marketing. He presented a framework for conceptualization which consists of two dimensions. These two dimensions consist of exchange interaction and short-term and long-term focus. This framework consists of four viewpoints such as internal marketing mix. Strategic internal marketing, processional internal marketing and internal relationship [Arefnejad,1390].

\section{The role and technique of branch manager is very important}

This research addresses the role and performance of bank manager from other perspective. Up to now/various researches and methods with regard to performance of account manager have been presented. Facilities should be proportionate with the number of customers.

Hence, it is incumbent upon manager to have a clear understanding about their customers and the scope of activities [Mehdi shamloo, 1385]. It is necessary that an account manager be a marketing strategist.

Today, bankers in order to gain more previledges, make use of retailors techniques. One of the most important and lucrative techniques. The strategy of finding proper market consists of recognizing intended customers, principal services, main competitors, potential customers, potential customers, analysis of swot, and adopting proper decisions [Farsad,1390].

\section{Effectiveness of relationship marketing}

Effectiveness of relationship marketing has been mooted in $1980 \mathrm{~s}$. The central purpose is to create value through long term relationship. One of the most important and lucrative techniques is to distinguish and find a stance market. The strategy of finding proper market intimate relationship within the frame work of potential customers, purposeful planning for gaining necessary resources, analysis of swot, and adopting proper decisions [Farsad,1390].

It has been attempted that relationship with customers strengthened and expanded. In addition to attracting customers pay special attention to keep and increase the customers. Within the framework of relationship marketing a learning relationship exists between bank and customers and this information can be used for the improvement of relationships. [farsad,1390].

\section{Conclusion}

Marketing is one of the tools which increase bank revenues. According to senior managers revenues Also, researches indicated that books by increasing the number of their customers, increase profits.

Books ability to provide their customers with services is a determining factor. As such, banks for being effective, need to have enough information, and understand their interests and needs. Keeping relationship with customers is a long- term issue. Instead of present results, future impacts should be the centre of attention. On the other hand the quality is of high importance, Different cultures have their own approaches. Middle East has long historical background. Middle eastern emphasized their social and personal interactions in order to strengthen their relationship with customers. 
Important factors in the success of banks consist of rapid and correct services and making their customers satisfied. Therefore dynamic and innovative organization comply itself with increasing need of customers. In fact in order to have dynamic and creative organization, active marketing is of high importance. We should comply with social, cultural, political, economic, technological and competitive factors. To this end we should be influential in the market place.

\section{REFERENCES}

Hossini, seyed jalil, Neyaki, ajdad,(1386), baking in theory and practice, termeh Publications, First Edition

Aref nejad, Mohsen, sobhani, Mohamad, Baloee. Jam khane, Hadi,Toghraee samirami, mahdi, (1390) Service marketing in bank Threagh DEA, Islamic Azad University firouzkoh Branch.

Sahraee, Fardin(1392), negotiation technique manual of matiane (center of health management.

Farsad, shokofe,(1390),marketing mangemnt, analysis of planning, implementation and control study of effective factor on the satisfaction of bank facilities aopplicants(case study: main and industry bank), Islamic Azad University neyshbor Branch

Forozandeh, Bahman,(1385), Marketing maement, Philip katler Amokhte publication, third edition

Adamson, I. and Chan, K. M. and Handford, D. (2003), "Relationship marketing: customer commitment and trust as strategy for the smaller Hong Kong corporate banking sector", International journal of bank marketing, Vol. 21, No. 6/7, pp: 347-358.

Gilbert, D. C. and Choi, K. C. (2003),"Relationship marketing practice in relation to different bank ownerships: a study of banks in Hong Kong", The International Journal of Bank Marketing, Vol. 21, No. 2/3, pp: 137-46.

Izquierdo, C.C \& Cillan, J. G. (2005),"The impact of customer relationship marketing on the firm performance", Journal of service Marketing, Vol. 19, No. 4, pp: 234-244.

Ndubisi, O. N. (2007), "Relationship marketing and customer loyalty", Marketing intelligence \& planning, Vol. 25, No. 1, pp: 98-106. 